\title{
EFFECT OF FERMENTATION ON THE QUALITY OF FLOUR AND BISCUIT
}

\section{FROM CASHEW KERNEL FLOUR}

\author{
*Bleou Jean Jaurès TOUZOU ${ }^{(1)}$, Doudjo SORO ${ }^{(2)}$, Soronikpoho SORO ${ }^{(1)}$, \\ Kouadio Ernest KOFFI ${ }^{(1)}$ \\ ${ }^{1}$ Laboratory of Biochemistry and Food Science, Training and Research Unit Biosciences, Félix Houphouët- \\ Boigny University of Abidjan, UFHB 01 BP V 34 Abidjan, Côte d'Ivoire, bleoutz@gmail.com \\ ${ }^{2}$ Food Science and Environmental Chemical Processes, Polytechnic National Institute, Félix Houphouët-Boigny \\ (INPHB), BP 1313 Yamoussoukro, Côte d'Ivoire. \\ *Corresponding author \\ Received $28^{\text {th }}$ December 2020, accepted $30^{\text {th }}$ March 2021
}

\begin{abstract}
The purpose of this paper is to investigate the effect of fermentation on the quality of cashew kernel flour for biscuit making. Fermented and unfermented cashew kernels flours produced were used to substitute wheat flour. Functional properties of flours were evaluated. Chemical and sensory characteristics of various biscuits obtained were used to compare them. Fermentation improved water absorption capacity, foaming and emulsification properties but reduced $(P<0.05)$ oil absorption capacity of cashew kernel flour. The analysis of nutritive values showed that fermentation increased the protein and fat contents respectively from $34.10 \pm 0.41$ to $38.67 \pm 0.4$ and from $28.16 \pm 0.07$ to $31.02 \pm 0.18$. Substitution of wheat flour by cashew kernels flours increase protein, fat, fiber and ash contents of biscuits. Biscuits from cashew kernel flour overall acceptability decreased with fermented cashew kernel flour incorporation. Negative correlation was observed between brown colour score and overall acceptability also between aroma (cashew kernel aroma and fermented cashew kernel aroma) scores and overall acceptability of biscuits. Panelists accepted regarding overall acceptability, biscuits containing $100 \%$ unfermented cashew kernel flour and those containing $40 \%$ of fermented cashew kernel flour. Substitution of wheat flour by unfermented cashew kernel flour and $40 \%$ by fermented cashew kernel flour would improve nutritive values of biscuits and cashew kernel consumption locally.
\end{abstract}

Keywords: Fermentation, Cashew kernels flours, substitution, quality, biscuits.

\section{Introduction}

Biscuits are a widely consumed food produced from wheat flour, sugar and fat [1]. However, the wheat imported by subSaharan African countries is expensive and the proteins, fibers and minerals content of the wheat flour commonly used (T45) for biscuit production is relatively low.

Research is being carried out to reduce the cost of biscuit production and to improve the functionality of biscuits by modifying their nutritional composition. This involves the use such as of non-wheat flour to improve nutritive quality of biscuits and overcome the high cost problems of wheat flour faced by importing countries whose climates are unfavorable to wheat growing $[2,3]$.

Acceptable biscuits have been produced from blends of fonio, wheat and cowpea; millet and pigeon pea; wheat and plantain; maize and pigeon pea $[4 ; 5 ; 6 ; 7]$. However, increasing the levels of cashew nut paste in the biscuits resulted in a significant decrease in the sensory attribute scores of the biscuits [8]. [9] also made similar findings.

Cashew nuts are the fruit of the cashew tree (Anarcadium occidentale) which is a widely grown in tropical region. Cashew trees are widely grown in several regions of Côte d'Ivoire, which is the world's largest producer of raw cashew nuts with $25 \%$ of world market share [10, 11]. 
Fermentation helps enhance the taste and aroma of food products [12]

This study assessed the effects of fermentation on the quality of flour prepared from cashew kernel. The quality of biscuits developed from composite flours containing cashew kernel fours and wheat flour were also investigated.

\section{Material and Methods}

\section{Material}

The small pieces of cashew kernel were obtained by mechanical shelling at the Fassou cashew factory based in Yamoussoukro (Côte d'Ivoire). Food ingredients including wheat flour, sugar, margarine, eggs, and baking powder were purchased from a supermarket in Yamoussoukro (Côte d'Ivoire).

\section{Methods}

Production of unfermented cashew kernel flour

Defatted cashew kernel flour was produced according to the modified method proposed by [13]. The cashew kernels were cleaned of plant debris and unhealthy kernels. The oil of the previously treated kernels was extracted twice with n-hexane at a ratio of 1: $1(\mathrm{w} / \mathrm{w})$. The oilcake were dried at $70^{\circ}$ $\mathrm{C}$ in an oven for 12 hours in order to remove traces of hexane before being reduced to flour using a hammer mill containing a 150 $\mu \mathrm{m}$ mesh. The resulting flour was stored in polyethylene bags at room temperature.

\section{Production of fermented cashew kernel flour}

The sorted kernels are fermented using the modified method described by [14]. Almonds $(1 \mathrm{~kg})$ are boiled at $100^{\circ} \mathrm{C}$ with distilled water $(\mathrm{w} / \mathrm{v})$ for 30 minutes. They are wrapped in plantain leaves to be fermented for 72 hours. The fermented kernels are dried in a ventilated oven at $65^{\circ}$ $\mathrm{C}$ for 48 hours. The fermented kernels oil was then extracted twice with n-hexane at a ratio of 1: $1(\mathrm{w} / \mathrm{w})$ as previously described. The oilcake were dried at $70^{\circ} \mathrm{C}$ in an oven for 12 hours in order to remove traces of hexane before being reduced to flour using a hammer mill containing a $150 \mu \mathrm{m}$ mesh. The flour is stored in polyethylene bags at room temperature.

\section{Preparation of Composite Flour}

Composites flours are prepared by substituting the wheat flour with unfermented cashew kernels flour or fermented cashew kernels flour in the ratio of 100:0, 80:20, 60:40, 40:60, 20:80 and 100:0 w/w.

\section{Functional properties analysis of flours}

Bulk density was determined by the method described by [15]. The Water absorption capacity (WAC) was determined by the method of [16]. The oil absorption capacity (OAC) was determined according to the method of [17]. Emulsion activity (EA) was carried out according to the method described by [18]. The foam capacity (FC) was determined by the method of [19].

\section{Biscuit production}

The recipe adopted after preliminary experimentation was as follows: flour (200 g), margarine (100 g), powdered sugar (100 $\mathrm{g})$, whole egg, baking powder (4 g), liquid milk (100 g/ L) (50 mL).

The margarine and the powdered sugar was creamed together at medium speed until light and fluffy appearance is formed. The flour is added to the cream and then homogenized. The egg and liquid milk were added to the cream. The flour previously mixed with baking powder and then sieved is introduced last. The ingredients are mixed and the dough obtained is prepared using a pocket. The dough pieces are placed on baking paper in trays and baked for 15 minutes in an oven preheated to $180^{\circ} \mathrm{C}$. 


\section{Nutritional composition of biscuits}

The moisture content and fat content of the various biscuits samples were performed using [20]. The crude protein and fat contents were respectively determined by estimating the nitrogen content using the Kjedahl and using the Soxhlet apparatus methods [21]. Ash and carbohydrate were respectively analysed using the method of [22] and [23]. Biscuit samples were analysed for fiber content according to the method described in [24]. Energy values were determined by methods described by [25].

\section{Sensory evaluation}

The descriptive test of the biscuits was carried out using the method described by [26]. Fifteen (15) trained panelists composed of women and men judged the samples. The method consists to quantify the appropriate descriptors (colour, texture, taste and aroma) according to a category 9 scale. All the instructions were provided to panelists before evaluation [27].

Biscuits were also evaluated by 60 panelists for overall acceptability on a 9-point hedonic scale $(1-$ extremely dislike, $2-$ dislike very much, 3 - dislike moderately, 4 - dislike slightly, 5- neither like nor dislike, 6 - like slightly, 7 - like moderately, 8 - like very much, 9 - extremely like) [27].

Different types of biscuit samples were presented in random order coded with random three-digit numbers on white plastic dishes, and served at the day of manufacture as well as under normal illumination (daylight). Water was provided to the panelists in order to cleanse their palates in between every sample.

\section{Statistical analysis}

Statistical analysis was carried out using Statistica 7.1. Soft software. The NewmanKeuls multiple means comparison test was used to verify differences between the samples. $\mathrm{P}<0.05$ was set as the criterion of significance.

\section{Results and Discussion}

The effect of cashew kernel fermentation and wheat flour substitution by cashew kernel flours on the functional properties is presented in Table 1. Water absorption capacity (WAC), oil absorption capacity (OCA), emulsifying activity (EA) and foaming capacity (FC) were significantly differs in the types of flours (Table 1).

Fermentation of cashew kernel for $72 \mathrm{~h}$ decreased the bulk density of the cashew kernel flour. [28] reported that bulk density depends on the combined effects of interrelated factors such as the intensity of attractive inter-particle forces, particle size, and number of contact points. The result is similar to that of [29] who reported that germination and fermentation leads to decrease in the bulk density of foods. The decrease in bulk density of the fermented flour would improve the fluidity of the slurry. Fermentation would therefore be a useful method for the preparation of weaning feeds [30].

Fermentation significantly $(\mathrm{p}<0.05)$ increased the water absorption capacity of cashew kernel flour. Also, wheat flour substitution by cashew kernels flours increased water absorption capacity of composite flours. The amount and nature of hydrophilic constituents such as proteins and to some extent the $\mathrm{pH}$ value favorably influence the water absorption capacity of a flour [31].

The correlation analysis revealed in Table 2 supported that the proteins content and water absorption capacity were highly positive correlated $(\mathrm{r}=0.98 \mathrm{p}<0.05)$. Proteolytic activity during fermentation may have increased the polar groups, which improved hydrophilicity of the cashew kernel flour proteins. 
In contrast, fermentation decreased significantly $(\mathrm{p}>0.05)$ the oil absorption capacity of cashew kernel flour.

Table 1

Functional properties of flours

\begin{tabular}{|l|c|c|c|c|c|}
\hline \multicolumn{1}{|c}{$\begin{array}{c}\text { Flours } \\
\text { samples }\end{array}$} & $\begin{array}{c}\text { Bulk Density } \\
\left(\mathbf{g} / \mathbf{m L}^{-1}\right)\end{array}$ & WAC (\%) & OAC (\%) & EA (\%) & FC (\%) \\
\hline WF & $0.63 \pm 0.05^{\mathrm{i}}$ & $109.75 \pm 1.5^{\mathrm{a}}$ & $89.52 \pm 0.9^{\mathrm{a}}$ & $48.27 \pm 0.7^{\mathrm{a}}$ & $35.7 \pm 0.05^{\mathrm{a}}$ \\
\hline UCF20 & $0.59 \pm 0.01^{\mathrm{h}}$ & $110.68 \pm 0.59^{\mathrm{b}}$ & $98.75 \pm 0.1^{\mathrm{c}}$ & $49.59 \pm 0.09^{\mathrm{b}}$ & $40.75 \pm 0.01^{\mathrm{b}}$ \\
\hline UCF40 & $0.56 \pm 0.08^{\mathrm{fg}}$ & $116 \pm 1.2^{\mathrm{c}}$ & $110.03 \pm 0.88^{\mathrm{e}}$ & $51.36 \pm 0.1^{\mathrm{d}}$ & $46.37 \pm 0.02^{\mathrm{d}}$ \\
\hline UCF60 & $0.51 \pm 0.02^{\mathrm{e}}$ & $128.21 \pm 1.3^{\mathrm{f}}$ & $118.79 \pm 0.64^{\mathrm{g}}$ & $53.28 \pm 0.19^{\mathrm{e}}$ & $52.78 \pm 0.07^{\mathrm{f}}$ \\
\hline UCF80 & $0.47 \pm 0.09^{\mathrm{cd}}$ & $133.12 \pm 0.5^{\mathrm{g}}$ & $126.28 \pm 0.55^{\mathrm{i}}$ & $55.32 \pm 0.25^{\mathrm{g}}$ & $59.07 \pm 0.05^{\mathrm{h}}$ \\
\hline UCF & $0.44 \pm 0.04^{\mathrm{b}}$ & $144.01 \pm 0.11^{\mathrm{i}}$ & $135.87 \pm 0.83^{\mathrm{k}}$ & $58.57 \pm 1.23^{\mathrm{i}}$ & $68.23 \pm 0.03^{\mathrm{j}}$ \\
\hline FCF20 & $0.57 \pm 0.07^{\mathrm{gh}}$ & $120.75 \pm 1.15^{\mathrm{d}}$ & $96.17 \pm 0.4^{\mathrm{b}}$ & $51.19 \pm 0.23^{\mathrm{c}}$ & $42.83 \pm 0.06^{\mathrm{c}}$ \\
\hline FCF40 & $0.54 \pm 0.03^{\mathrm{f}}$ & $123.27 \pm 1.26^{\mathrm{e}}$ & $107.22 \pm 0.7^{\mathrm{d}}$ & $54.97 \pm 0.07^{\mathrm{f}}$ & $47.66 \pm 0.06^{\mathrm{e}}$ \\
\hline FCF60 & $0.48 \pm 0.05^{\mathrm{de}}$ & $139.33 \pm 1.24^{\mathrm{h}}$ & $111.98 \pm 0.95^{\mathrm{f}}$ & $56.79 \pm 0.13^{\mathrm{h}}$ & $54.17 \pm 0.06^{\mathrm{g}}$ \\
\hline FCF80 & $0.45 \pm 0.04^{\mathrm{bc}}$ & $148.19 \pm 1.1^{\mathrm{j}}$ & $116.07 \pm 0.9^{\mathrm{h}}$ & $60.88 \pm 0.35^{\mathrm{j}}$ & $64.57 \pm 0.03^{\mathrm{i}}$ \\
\hline FCF & $0.4 \pm 0.06^{\mathrm{a}}$ & $154.83 \pm 0.89^{\mathrm{k}}$ & $123.4 \pm 0.28^{\mathrm{j}}$ & $64.81 \pm 1.85^{\mathrm{k}}$ & $72.3 \pm 0.03^{\mathrm{k}}$ \\
\hline
\end{tabular}

Values are means of triplicate replications. Means within a column with different superscript were significantly ( $p<0.05)$ different. UCF : Unfermented cashew kernel flour; UCF80: 20 wheat flour +80 unfermented cashew kernel flour; UCB60: 40 wheat flour +60 unfermented cashew kernel flour; $\boldsymbol{U C B}$ 40: 60 wheat flour +40 unfermented cashew kernel flour; UCB20: 80 wheat flour +20 unfermented cashew kernel flour; FCB: fermented cashew kernel flour; FCB80: 20 wheat flour +80 fermented cashew kernel flour; FCB60: 40 wheat flour + 60 fermented cashew kernel flour; FCB40: 60 wheat flour +40 fermented cashew kernel flour; FCB20: 80 wheat flour +20 fermented cashew kernel flour; WF: wheat flour.

The result however agrees with the work of [32] who observed a significant decrease in oil absorption capacity of defatted coconut (Cocos nucifera L.) flour with increase in fermentation time. The decrease observed could be attributed to the increase in the fat content during the fermentation process [33]. Unfermented and fermented cashew kernel flours has a higher oil absorption capacity than wheat flour. The higher oil absorption capacity suggest that these flours would be useful in formulation of foods such as biscuits and cakes where oil absorption capacity is an important consideration.

Resullts (Table 1) showed that fermented cashew kernel flour had high emulsion activity (EA). Fermentation had significantly increased $(\mathrm{P}<0.05)$ the emulsion activity. The emulsifying activity is the work of soluble proteins, which, present at the water and oil interface, promote the formation of emulsions [34]. The fermentation would therefore make the proteins more soluble, thus promoting the formation of more emulsions in the fermented cashew kernel flour. These results are in agreement with the work of [35] who observed an increase in emulsifying capacity during the fermentation of sorghum flour. Wheat flour substitution by cashew kernels flours increased emulsion activity of composite flours.

The emulsifying activity has utility in the preparation of pastry and bakery products [36].

The increase in foaming capacity is thought to be due to the reduction of the surface tension of proteins because of the hydrolysis of proteins into amino acids during fermentation [37]. Foams are used to improve texture, consistency and appearance of foods. 
Table 3 shows positive correlation between proteins and fibers contents and functional properties (WAC, OAC, EA and FC). These positive correlations indicate that incorporation rates of cashew kernels flours increase significantly $(\mathrm{P}<0.05)$ functional properties of composite flours.

Table 2

Correlation coefficients among functional properties analysis of flours, Nutritional composition and Sensory evaluation of biscuits.

\begin{tabular}{|c|c|c|c|c|c|c|c|c|c|c|c|c|c|}
\hline & Proteins & Carbohydrates & Fat & Fibres & WAC & OAC & EA & FC & Brown colour & Firmness & Crispness & Aroma & Oveall accep \\
\hline Proteins & 1.00 & & & & & & & & & & & & \\
\hline Carbohydrates & -0.99 & 1.00 & & & & & & & & & & & \\
\hline Fat & 0.98 & -0.99 & 1.00 & & & & & & & & & & \\
\hline Fiber & 0.62 & -0.67 & 0.74 & 1.00 & & & & & & & & & \\
\hline WAC & 0.98 & -0.97 & 0.95 & 0.55 & 1.00 & & & & & & & & \\
\hline OAC & 0.83 & -0.86 & 0.90 & 0.95 & 0.77 & 1.00 & & & & & & & \\
\hline EA & 0.84 & -0.81 & 0.77 & 0.22 & 0.87 & 0.46 & 1.00 & & & & & & \\
\hline FC & 0.98 & -0.98 & 0.99 & 0.74 & 0.95 & 0.89 & 0.78 & 1.00 & & & & & \\
\hline Brown colour & 0.81 & -0.77 & 0.71 & 0.15 & 0.86 & 0.43 & 0.79 & 0.70 & 1.00 & & & & \\
\hline Firmness & -0.88 & 0.90 & -0.91 & -0.75 & -0.86 & -0.89 & -0.62 & -0.87 & -0.62 & 1.00 & & & \\
\hline Crispness & -0.91 & 0.92 & -0.92 & -0.64 & -0.91 & -0.82 & -0.65 & -0.88 & -0.81 & 0.92 & 1.00 & & \\
\hline Aroma & 0.95 & -0.93 & 0.92 & 0.57 & 0.96 & 0.77 & 0.77 & 0.91 & 0.89 & -0.84 & -0.93 & 1.00 & \\
\hline Overall accep & -0.94 & 0.92 & -0.88 & -0.37 & -0.97 & -0.62 & -0.91 & -0.88 & -0.93 & 0.76 & 0.87 & -0.94 & 1.00 \\
\hline
\end{tabular}

Correlations in bold are significant at the 0.05 level

The results in Table 3 show a significant difference $(p<0.05)$ between the nutritional characteristics of biscuits containing cashew kernels (unfermented cashew kernels flour or fermented cashew kernels flour) and biscuits made from $100 \%$ wheat flour nutritional values.

Indeed, the incorporation rates of cashew kernels flours allow an increase in proteins, lipids, ash and fibers content. It is well documented that cashew kernel is a major source of proteins, fat, ash and fiber [38; 39]. The inclusion of cashew kernel flours to the formulation decreased the carbohydrate content with regard to the control sample.

Proximate Composition of biscuits

\begin{tabular}{|c|c|c|c|c|c|c|c|}
\hline \multirow[b]{2}{*}{ Samples } & \multicolumn{7}{|c|}{ Parameters } \\
\hline & $\begin{array}{c}\text { Moisture } \\
\text { (g/100g) }\end{array}$ & $\begin{array}{l}\text { Proteins } \\
\text { (g/100g) }\end{array}$ & $\begin{array}{c}\text { Fat } \\
(\mathrm{g} / \mathbf{1 0 0 g})\end{array}$ & $\begin{array}{c}\text { Carbohydrate } \\
(\mathrm{g} / 100 \mathrm{~g})\end{array}$ & $\begin{array}{c}\text { Ash } \\
(\mathrm{g} / \mathbf{1 0 0 g})\end{array}$ & $\begin{array}{c}\text { Fiber } \\
(\mathrm{g} / 100 \mathrm{~g})\end{array}$ & $\begin{array}{c}\text { Energy } \\
(\text { kcal/100g) }\end{array}$ \\
\hline $\mathbf{W B}$ & $3.40 \pm 0.02^{\mathrm{a}}$ & $12.77 \pm 0.23^{a}$ & $10.36 \pm 0.09^{\mathrm{a}}$ & $0.98 \pm 0.15^{\mathrm{a}}$ & $71.48 \pm 0.57^{\mathrm{k}}$ & $1.39 \pm 0.2^{\mathrm{a}}$ & $430.28 \pm 0.3^{a}$ \\
\hline UCB20 & $3.53 \pm 0.08^{b}$ & $16.35 \pm 0.09^{b}$ & $12.18 \pm 0.05^{b}$ & $1.42 \pm 0.04^{\mathrm{c}}$ & $66.51 \pm 0.11^{\mathrm{j}}$ & $1.91 \pm 0.2^{\mathrm{d}}$ & $441.35 \pm 0.32^{\mathrm{b}}$ \\
\hline UCB 40 & $3.86 \pm 0.04^{\mathrm{d}}$ & $18.53 \pm 0.25^{\mathrm{d}}$ & $15.53 \pm 0.10^{\mathrm{d}}$ & $1.90 \pm 0.08^{\mathrm{f}}$ & $60.16 \pm 0.2^{h}$ & $2.49 \pm 0.1^{\mathrm{g}}$ & $454.51 \pm 0.2^{\mathrm{d}}$ \\
\hline UCB60 & $4.06 \pm 0.02^{f}$ & $25.25 \pm 0.07^{f}$ & $20.52 \pm 0.35^{\mathrm{f}}$ & $2.38 \pm 0.05^{\mathrm{i}}$ & $47.62 \pm 0.39^{f}$ & $3.04 \pm 0.3^{\mathrm{i}}$ & $476.74 \pm 0.14$ \\
\hline UCB 80 & $4.23 \pm 0.06^{\mathrm{g}}$ & $29.60 \pm 0.11^{\mathrm{h}}$ & $26.88 \pm 0.20^{h}$ & $2.84 \pm 0.19^{j}$ & $36.39 \pm 0.45^{\mathrm{d}}$ & $3.63 \pm 0.6^{j}$ & $506.16 \pm 0.1^{\mathrm{h}}$ \\
\hline UCB & $4.35 \pm 0.01^{\mathrm{i}}$ & $34.10 \pm 0.41^{\mathrm{g}}$ & $28.16 \pm 0.07^{i}$ & $3.32 \pm 0.15^{\mathrm{k}}$ & $30.11 \pm 0.24^{\mathrm{b}}$ & $3.99 \pm 0.4^{\mathrm{k}}$ & $510.26 \pm 0.34^{\mathrm{i}}$ \\
\hline FCB20 & $3.73 \pm 0.05^{\mathrm{c}}$ & $17.79 \pm 0.37^{\mathrm{c}}$ & $13.97 \pm 0.09^{c}$ & $1.23 \pm 0.07^{b}$ & $63.27 \pm 0.34^{\mathrm{i}}$ & $1.65 \pm 0.1^{\mathrm{b}}$ & $450.03 \pm 0.2^{\mathrm{c}}$ \\
\hline FCB 40 & $3.96 \pm 0.07^{\mathrm{e}}$ & $23.15 \pm 0.10^{\mathrm{e}}$ & $17.83 \pm 0.24^{\mathrm{e}}$ & $1.51 \pm 0.12^{\mathrm{d}}$ & $53.54 \pm 0.16^{\mathrm{g}}$ & $1.87 \pm 0.2^{\mathrm{c}}$ & $467.17 \pm 0.19^{e}$ \\
\hline FCB & $4.27 \pm 0.09^{\mathrm{h}}$ & $26.93 \pm 0.29^{\mathrm{g}}$ & $22.55 \pm 0.15^{\mathrm{g}}$ & $1.77 \pm 0.2^{\mathrm{e}}$ & $44.46 \pm 0.28^{\mathrm{e}}$ & $2.19 \pm 0.3^{\mathrm{e}}$ & $488.55 \pm 0.4^{\mathrm{g}}$ \\
\hline FCB80 & $4.52 \pm 0.03^{j}$ & $33.93 \pm 0.17^{\mathrm{i}}$ & $27.97 \pm 0.06^{\mathrm{j}}$ & $2.05 \pm 0.24^{\mathrm{g}}$ & $31.52 \pm 0.11^{\mathrm{c}}$ & $2.43 \pm 0.1^{\mathrm{f}}$ & $513.52 \pm 0.1^{\mathrm{j}}$ \\
\hline FCB & $4.73 \pm 0.05^{\mathrm{k}}$ & $38.67 \pm 0.4^{\mathrm{k}}$ & $31.02 \pm 0.18^{k}$ & $2.33 \pm 0.16^{\mathrm{h}}$ & $23.26 \pm 0.13^{a}$ & $2.74 \pm 0.1^{\mathrm{h}}$ & $526.86 \pm 0.28^{k}$ \\
\hline
\end{tabular}

Values are means of triplicate replications. Means within a column with different superscript were significantly $(p<0.05)$ different. WB: wheat flour biscuit; UCB20: 80 \% wheat flour $+20 \%$ unfermented cashew kernel flour biscuit; UCB40: $60 \%$ wheat flour +40 $\%$ unfermented cashew kernel flour biscuit; UCB60: $40 \%$ wheat flour $+60 \%$ unfermented cashew kernel flour biscuit; UCB80: 20 $\%$ wheat flour $+80 \%$ unfermented cashew kernel flour biscuit; UCB: Unfermented cashew kernel flour biscuit; FCB20: $80 \%$ wheat flour + $20 \%$ fermented cashew kernel flour biscuit; FCB40: $60 \%$ wheat flour $+40 \%$ fermented cashew kernel flour biscuit; FCB 60: $40 \%$ wheat flour $+60 \%$ fermented cashew kernel flour biscuit; FCB80: $20 \%$ wheat flour $+80 \%$ fermented cashew kernel flour biscuit; FCB: fermented cashew kernel flour biscuit.

Bleou Jean Jaurès TOUZOU, Doudjo SORO, Soronikpoho SORO, Kouadio Ernest KOFFI, Effect of fermentation on the quality of flour and biscuit from cashew kernel flour, Food and Environment Safety, Volume XX, Issue 1 - 2021, pag. 81 - 90 
At the same incorporation rate of cashew kernel flour, biscuits containing fermented cashew kernel flour and those containing unfermented cashew kernel flour have significantly different.

Fermentation helps to increase significantly $(\mathrm{p}<0.05)$ proteins content. This trend is similar to the observations of [40] who found a significant increase in proteins content of soybean (Glycine max), Cowpea (Vigna unguiculata) and ground bean (Macrotyloma geocarpa) after fermentation. This increase could be attributed to the increase in microbial mass during fermentation, causing extensive hydrolysis of proteins to amino acids and other simple peptides [41]. The crude fibers decrease from 20.16 to $17.20 \mathrm{~g} / 100 \mathrm{~g}$ after fermentation. This could result from the degradation of fibers by microorganisms [42]. On the other hand, the content of carbohydrates and fiber are reduced by fermentation.

The sensory characteristics of a product are an important aspect in the overall acceptability of that product.
Figures 1 and 2 shows the sensory profiles of the unfermented cashew kernels flours biscuits and the fermented cashew kernel flour biscuits, respectively. The browning of the biscuits is significant $(\mathrm{P}<0.05)$ more noticeable in the case of biscuits based on fermented cashew kernels than with the biscuits based on unfermented cashew kernel flour. Biscuits made from fermented or unfermented cashew kernel flours have a significantly higher intensity of brown colour $(\mathrm{P}<0.05)$ than that of the control biscuit (100\% wheat). The perception of brown colour in biscuits increases significantly with the rate of substitution of wheat flour by cashew kernel flours (fermented cashew kernel flour or unfermented cashew kernel flour). A significant and positive correlation $(\mathrm{r}=$ 0.81 ) between protein content and biscuits brown colour intensity is observed. The proteins in the presence of reducing sugars, by the Maillard reaction favors the production of browner biscuits [43]. The browning of biscuits decreases the colour acceptability score.

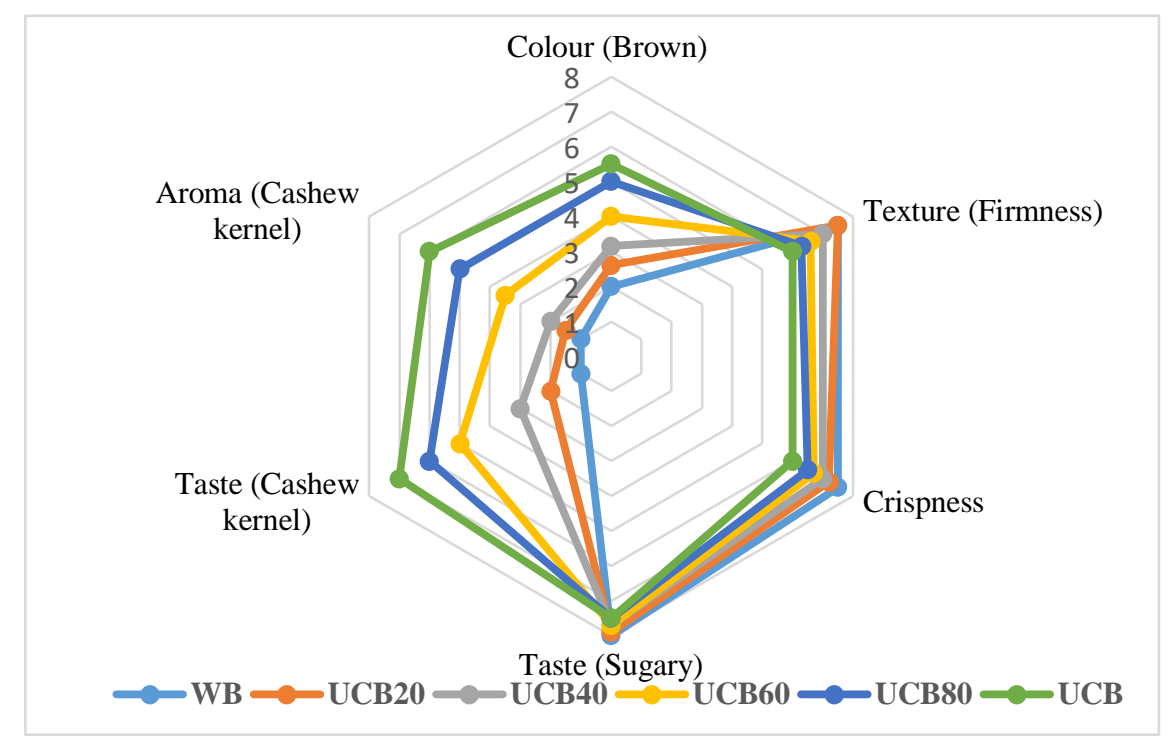

Fig. 1. Sensory profile of biscuits made from unfermented cashew kernel flour and wheat flour

Results are presented as the mean $(n=15)$.WB: wheat flour biscuit; $\boldsymbol{U C B 2 0 :} 80 \%$ wheat flour $+20 \%$ unfermented cashew kernel flour biscuit; UCB40: $60 \%$ wheat flour + $40 \%$ unfermented cashew kernel flour biscuit; UCB60: $40 \%$ wheat flour $+60 \%$ unfermented cashew kernel flour biscuit; UCB80: $20 \%$ wheat flour $+80 \%$ unfermented cashew kernel flour biscuit; $\boldsymbol{U C B}$ : Unfermented cashew kernel flour biscuit.

Bleou Jean Jaurès TOUZOU, Doudjo SORO, Soronikpoho SORO, Kouadio Ernest KOFFI, Effect offermentation on the quality of flour and biscuit from cashew kernel flour, Food and Environment Safety, Volume XX, Issue 1 - 2021, pag. 81 - 90 


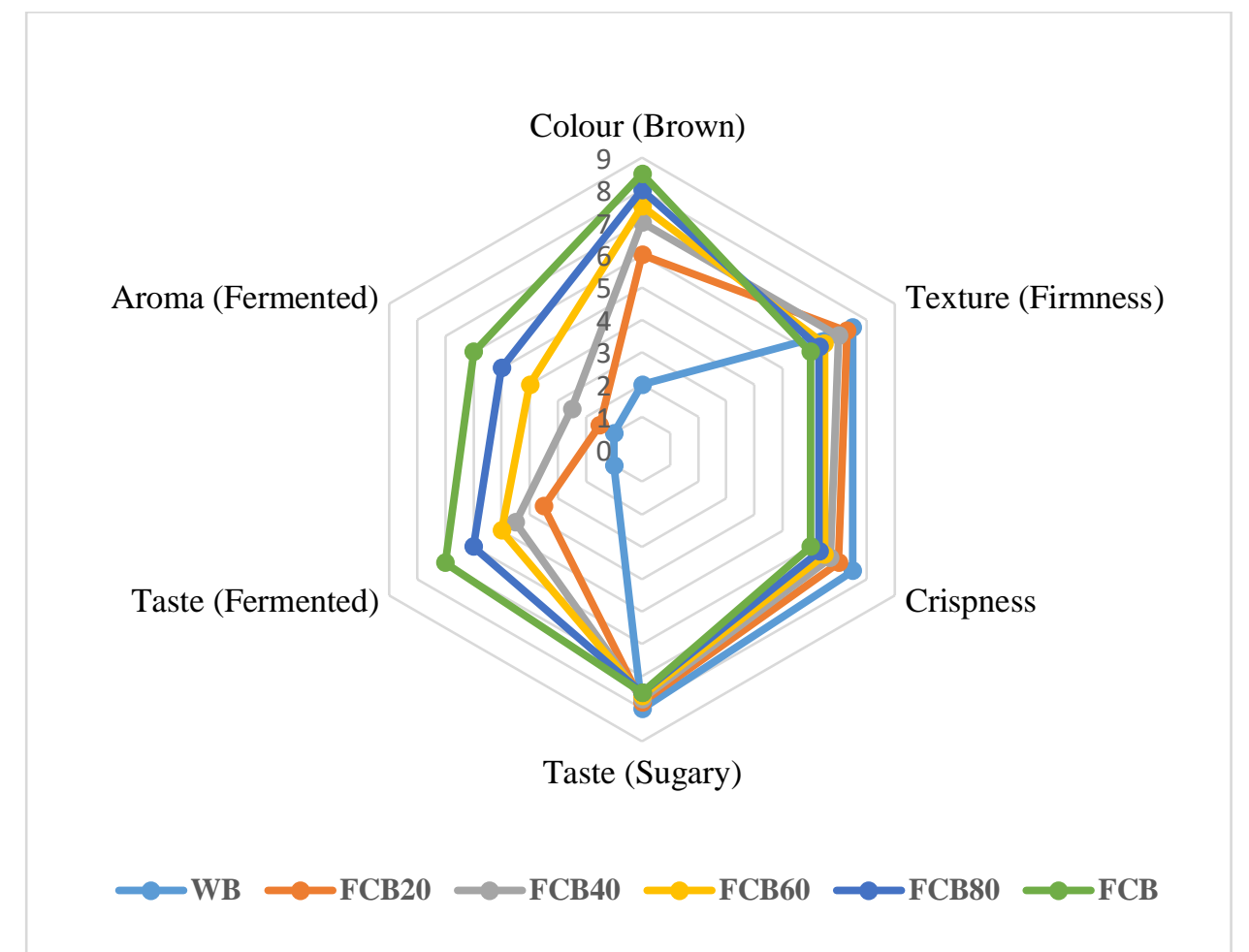

Fig. 2. Sensory profile of biscuits made from fermented cashew kernel flour and wheat flour

Results are presented as the mean $(n=15)$. WB: wheat flour biscuit; $\mathbf{F C B 2 0 :} 80 \%$ wheat flour $+20 \%$ fermented cashew kernel flour biscuit; FCB40: 60 \% wheat flour + $40 \%$ fermented cashew kernel flour biscuit; FCB 60: $40 \%$ wheat flour $+60 \%$ fermented cashew kernel flour biscuit; FCB80: $20 \%$ wheat flour $+80 \%$ fermented cashew kernel flour biscuit; FCB: fermented cashew kernel flour biscuit.

The descriptors "cashew kernel taste" and "cashew kernel aroma" are significantly (P $<0.05)$ perceived by the panelists when tasting the biscuits produced from $60 \%$ substitution rate for wheat flour by unfermented cashew kernel flour. While the descriptors "fermented taste" and "fermented aroma" are significantly, ( $<$ < $0.05)$ perceived from $40 \%$ substitution rate of wheat flour by fermented cashew kernel flour. Biscuits based on unfermented cashew kernel flour and those based on fermented cashew kernel flour show no significant difference $(\mathrm{P}<0.05)$ in firmness and crispness. Wheat flour biscuits have the highest intensity of firmness and crispness. It is also observed that the perception of the intensity of the crispness and the firmness of biscuits based on composite flours (cashew kernel/ wheat) decreases due to the substitution of wheat flour by kernel flours of cashew (fermented and unfermented cashew kernel flour).

Composite flour biscuits are significantly ( $\mathrm{P}$ $<0.05$ ) less firm from $60 \%$ substitution rate for wheat flour with cashew kernel flours. The results (Table 4) showed that cashew kernel fermentation and the substitution of wheat flour for cashew kernels flours influences negatively overall acceptability of biscuits made from composite flours. This decrease in overall acceptability could be explained by the hedonic characteristics (colour, aroma, taste) of cashew kernels flours. This interpretation could further be supported by the results obtained from the correlation analysis. As shown in Table 2, Brown colour, cashew kernel aroma and fermented aroma negatively correlated with overall acceptability $(r=-0.93$ and $r=-0.94$, respectively

Bleou Jean Jaurès TOUZOU, Doudjo SORO, Soronikpoho SORO, Kouadio Ernest KOFFI, Effect of fermentation on the quality of flour and biscuit from cashew kernel flour, Food and Environment Safety, Volume XX, Issue 1 - 2021, pag. 81 - 90 
Overall acceptability of biscuits

Table 4

\begin{tabular}{cc}
\hline Biscuit samples & Overall Acceptability \\
\hline WB & $8.28 \pm 0.95^{\mathrm{g}}$ \\
UCB20 & $8.23 \pm 13^{\mathrm{g}}$ \\
UCB40 & $8.20 \pm 1.18^{\mathrm{g}}$ \\
UCB60 & $7.58 \pm 0.97^{\mathrm{f}}$ \\
UCB80 & $7.51 \pm 0.84^{\mathrm{ef}}$ \\
UCB & $7.44 \pm 1.11^{\mathrm{e}}$ \\
FCB20 & $7.57 \pm 1.52^{\mathrm{f}}$ \\
FCB40 & $6.72 \pm 1.03^{\mathrm{d}}$ \\
FCB60 & $4.82 \pm 1.25^{\mathrm{c}}$ \\
FCB80 & $4.75 \pm 1.26^{\mathrm{b}}$ \\
FCB & $4.68 \pm 1.47^{\mathrm{a}}$ \\
\hline
\end{tabular}

Means $(n=60)$ within a column with different superscript were significantly $(p<0.05)$ different.

WB: wheat flour biscuit; UCB20: $80 \%$ wheat flour $+20 \%$ unfermented cashew kernel flour biscuit; UCB40: $60 \%$ wheat flour +40 $\%$ unfermented cashew kernel flour biscuit; UCB60: $40 \%$ wheat flour $+60 \%$ unfermented cashew kernel flour biscuit; UCB80: 20 $\%$ wheat flour $+80 \%$ unfermented cashew kernel flour biscuit; UCB: Unfermented cashew kernel flour biscuit; FCB20: $80 \%$ wheat flour + $20 \%$ fermented cashew kernel flour biscuit; FCB40: $60 \%$ wheat flour $+40 \%$ fermented cashew kernel flour biscuit; FCB 60: $40 \%$ wheat flour $+60 \%$ fermented cashew kernel flour biscuit; FCB80: $20 \%$ wheat flour $+80 \%$ fermented cashew kernel flour biscuit; FCB: fermented cashew kernel flour biscuit.

Sensory attributes decrease when chickpea flour is added to bread [44]. In addition, fermentation induced alteration in food thereby the protein and fat may be degraded with consequent effect upon food flavor and texture [45]. With the cashew kernel, the panelists have depreciated these changes. There is no significant difference at the $5 \%$ threshold between biscuits prepared with 80 $\%$ wheat flour and $20 \%$ unfermented cashew kernel flour (UCB20), biscuits with $60 \%$ wheat flour and $40 \%$ unfermented cashew kernel flour (UCB40) and biscuits prepared with $100 \%$ wheat flour (WB).

\section{Conclusion}

The substitution of wheat flour for cashew kernels flours has improved the protein, ash fiber content, and energy value of biscuits. The incorporation of $20 \%$ and $40 \%$ unfermented cashew kernel flour could enrich the biscuits without significantly affecting their overall acceptability. The members of the panel accepted biscuit produced with unfermented cashew kernel flour and biscuits produced with composite flour containing $40 \%$ fermented cashew kernel flour. The consumption of these biscuits could reduce the cost of importing wheat, increase the processing level of cashew at the local level and helped to fight malnutrition in Africa.

\section{References}

[1]. O'BRIENA C. M., CHAPMANB D., NEVILLE D. P., KEOGH M. K., ARENDT E. K., Effect of varying the micro-encapsulation process on the functionality of hydrogenated vegetable fat in short dough biscuits. Fd. Res. Int., 36:215-221, (2003).

[2]. AYO J. A., NKAMA I., ADEWORI R. , Physicochemical, invitro digestibility and organoleptic evaluation of "acha"-wheat biscuit supplemented with soybean flour, Nig. Fd. J., 25(2):77-89, (2007).

[3]. AKUBOR P. I., Protein contents, physical and sensory properties of Nigerian snack Food (cake, Chin-chin and puff-puff) prepared from cowpeawheat flour blends, Int. J. Fd. Sci. Tech., 39(4):419424, (2004).

[4]. MCWATTERS K. H., OUEDRAOGO J. B., RESURRECCION A. V. A., HUNG Y. PHILLIPS V., Physical and sensory characteristics of sugar cookies containing mixtures of wheat, fonio (Digitaria exilis) and cowpea (Vigna unguiculata) flours, Int. J. Food Sci. Tech., 38:403-410, (2003).

Bleou Jean Jaurès TOUZOU, Doudjo SORO, Soronikpoho SORO, Kouadio Ernest KOFFI, Effect offermentation on the quality of flour and biscuit from cashew kernel flour, Food and Environment Safety, Volume XX, Issue 1 - 2021, pag. 81 - 90 
[5]. ENECHE E. H., Biscuit making potentials of millet/pigeon pea flour blends, Plant Foods Hum. Nutr., 54: 21-27, (2003).

[6]. MEPBA H. D., EBOH L., NWAOJIGWA S. U., Chemical composition, Functional and Baking Properties of Wheat- Plantain Composite Flours, Afr. J. Food Agric. Nutr. Dev., 7(1): 1-22, (2007).

[7]. ECHENDU C. A, ONIMAWO I. A., SOMTOCHI A., Production and Evaluation of Doughnuts and Biscuits from Maize- Pigeon pea Flour Blends, Nig. Food J., 22: 147-153, (2004).

[8]. OJINNAKA M. C. \& AGUBOLUM F. U., Nutritional and sensory properties of cashew nutwheat based cookies, American journal of food and nutrition, 33: 127-134, (2013).

[9]. AROYEUN S. O., Utilization of cashew kernel meals in the nutritional enrichment of biscuit, African Journal of Food Science, 3(10): 316-319, (2009).

[10]. FAOSTAT. Cashew nut production quantities by country, (2015).

[11]. CCA (Conseil Coton Anacarde en Côte d'Ivoire), Publié le lundi 15 février 2016.

[12]. KOKO A. C., KONAN A., TETCHI F., ASSIDJO E. \& AMANI G. Quality of fermented cassava flour processed into placali. International Journal of Biology chemestry Science, 6(1): 415420, (2012).

[13]. SZE-TAO K. W. C. \& SATHE S. K., Functional properties and in-vitro digestibility of Almond (Prunusdulcis L) protein isolate, Food chemistry, 69: 153-16, (2004).

[14]. IJAROTIMI O. S., OLUWALANA I. B. \& OGUNEDOJUTIMI M. O., Nutrient composition, functional, sensory and microbial status of popcorn based (zea may everta) complementary foods enriched with cashew nut (anacardium occidentale l.) flour, African Journal of Food Science, 12(5): 6424-6446, (2012).

[15]. CHAU C. F. \& HUANG Y. L., Comparison of the chemical composition and physicochemical properties of different fibers prepared from the peel of Citrus sinensis L. Cv. Liucheng, Journal of Agricultural Food and Chemistry, 51(9): 2615-2618, (2003).

[16]. PHILIPS R. D., CHINNAN M. S., BRANCH A. L., MILLER J. \& MCWATTERS K. H., Effects of pretreatment on functional and nutritional properties of cowpea meal, Journal of Food Science, 53: 805-809, (1988).

[17]. SOSULSKI F. W., The centrifuge method for determining flour absorption in hard red spring wheat, Cereal Chemistry, 39: 344-350, (1962).

[18]. NETO V. Q., NARAIN N., SILVIA J. B. \& BORA P. S., Functional properties of raw and heatprocessed cashew nut (Anarcadium occidentale L.) kernel protein isolate, Nahrung, (45): 258-262, (2001).

[19]. BENCINI M. C., Functional Properties of Drum-Dried Chickpea (Cicer arietinum L.) Flours, Journal of Food Science, 51(6), 1518-1521, (1986). [20]. AOAC, Official Methods of Analysis of the Association of Official Analytical Chemists, 15 th edition, Virgina, 217 p, (1999).

[21]. AOAC, Official methods of analysis of the Association of Official Analytical Chemists, $15^{\text {th }}$ edition, Washington DC, $1230 \mathrm{p}$, (1990).

[22]. AOAC, Official method of analysis of Association of Official Analytical Chemists, $17^{\text {th }}$ edition, Gaithersburg, 2200 p, (2000).

[23]. AOAC, Official method of analysis of the Association of Official Analytical Chemist, $5^{\text {th }}$ edition, AOAC Press, Arlington, Virginia, USA, (2005).

[24]. Van Soest P. S., Use of detergents in the analysis of fibrous feeds II- A rapid method for the determination of fiber and lignin, Journal of Association of Official Analytical Chemistry, 46: 829-835, (1963).

[25]. ATWATER W. \& ROSA E., A new respiratory calorimeter and the conservation of energy in human body, II-physical, 9: 214-251, (1899).

[26], [27]. MEILGAARD M., CIVILLE G. V. \& CARR B. T., Sensory Evaluation Techniques. CRC Press, Boca Raton. 281 p, (1999).

[28] PELEG M., Physical characteristics of food powders, InPhysical Properties of Foods (eds. M. Peleg and E. B. Bagley), 293-324, (1983).

[29]. ONIMAWO I. A., AKUBUR P. I., Food Chemistry .Ambik press Ltd, (2005).

[30]. ARIAHU C. C., UKPABI U. \& MBAJUNWA K. O., Production of African breadfruit (Treculia africana) and soybean (Glycine max) seed based food formulations, Plant Foods Hum. Nutri., 54: 192-206, . (1999).

[31]. ONIMAWO I. A. \& AKUBOR P. I., Food Chemistry (Integrated Approach with Biochemical background, 2 nd edition Joytal printing press, Agbowo, Ibadan, Nigeria, (2012).

[32], [33]. IGBABUL B. D., AMOVE. J. \& TWADUE I., Effect of fermentation on the proximate composition, antinutritional factors and functional properties of cocoyam (Colocasia esculenta) flour, African Journal of Food Science and Technology, 5(3): 67-74, (2014).

[34]. MOURE A., SINEIRO J., DOMINGUEZ H. \& PARAJO J. C., Functionally of oil seed protein products: a review, Food research international, 38(9): 945-963, (2006).

[35]. ABD ELMONEIM O. E., SCHIFFLER B. \& BERNHARDT R., Effect of fermentation on the functional properties of sorghum flour, Food Chemistry, 92(1): 1-5, (2004).

Bleou Jean Jaurès TOUZOU, Doudjo SORO, Soronikpoho SORO, Kouadio Ernest KOFFI, Effect offermentation on the quality of flour and biscuit from cashew kernel flour, Food and Environment Safety, Volume XX, Issue 1 - 2021, pag. 81 - 90 
[36]. AKUBOR P. I. \& BADIFU G. L. O., Chemical Composition, Functional Properties and Baking Potential of African breadfruit kernel and Wheat flour blends, International Journal of Food Science \& Technology, 39: 223-229, (2004).

[37]. SOSULSKI F. W., GARRATT M. O. \& SLINKARD E. A., Functional properties of Instit. Food Sci. Technol. J., 19:66-69, (1976).

[38]. FREITAS J. B., NAVES M. M. V., Chemical composition of nuts and edible seeds and their relation to nutrition and health, Rev. Nutr. Campinas, 23(2): 269-279, (2010).

[39]. AKINHANMI T. F., ATASIE V. N., Chemical Composition and Physicochemical Properties of Cashew nut (Anacardium occidentale) Oil and Cashew nut Shell Liquid, J. Agric. Food Environ. Sci. 2(1): 1-10, (2008).

[40]. EGOUNLETY M., Production properties and utilization of mould fermented foods from soybean (Glycine max. M.) cowpea (Vigna unguiculata $l$. Walp) and ground bean (Macrotyloma geocarpa $\mathrm{H}$.). Ph.D Thesis. University of Ibadan, Nigeria. pp 2128, (1994).
[41]. IGBABUL B. D., AMOVE J., TWADUE I., Effect of fermentation on the proximate composition, antinutritional factors and functional properties of cocoyam (Colocasia esculenta) flour, Afr. J. Food Sci. Technol. 5(3): 67-74, (2014).

[42]. BABALOLA R. O., GIWA O. E., Effect of fermentation on nutritional and anti-nutritional properties of fermenting Soy beans and the antagonistic effect of the fermenting organism on selected pathogens, International Research Journal of Microbiology, 3(10): 333-338, (2012).

[43].MANNAY.S SHADAKSHARASWANY C. M. (2005) Foods: Facts and principes, $2^{\text {nd }}$ edition. New Age International Ltd. Publishers. New Delhi, India, (2005).

[44]. MAN S., PĂUCEAN A., MUSTE S., \& POP A., Effect of the chickpea (Cicer arietinum L.) flour addition on physicochemical properties of wheat bread, Bulletin of University of Agricultural Sciences and Veterinary Medicine Cluj-Napoca. Food Science and Technology, 72(1), 41-49, (2015).

[45]. KOMOLAFE I. O. Cereal crops and their food in tropical, Afr. J. Agri 62: 105-116, (2002).

Bleou Jean Jaurès TOUZOU, Doudjo SORO, Soronikpoho SORO, Kouadio Ernest KOFFI, Effect offermentation on the quality of flour and biscuit from cashew kernel flour, Food and Environment Safety, Volume XX, Issue 1 - 2021, pag. 81 - 90 